\title{
RELASI DAYAK-BANJAR DALAM TUTUR MASYARAKAT DAYAK MERATUS*
}

\begin{abstract}
Ahmad Rafiq $^{* *}$
ABSTRAK

Etnis Dayak dan Banjar pada awalnya berasal dari rumpun etnik yang sama. Namun kemudian diidentifikasi secara berbeda tidak hanya melalui etnisitas, tetapi juga agama mereka. Dayak identik dengan Kaharingan sebagai agama asli mereka, sementara Banjar identik dengan Islam sebagai agama yang baru mulai dianut sejak didirikannya Kesultanan Islam Banjar oleh Pangeran Samudera. Semenjak itu, perbedaan identitas ini direspon oleh orang Dayak melalui mitos atau folklore. Mitos-mitos ini, berdasarkan riset lapangan yang telah dilakukan oleh penulis artikel ini, dipahami sebagai seperangkat simbol yang mengungkapkan tipologi relasi orang Dayak dengan Banjar. Paling tidak, ada empat tipologi relasi yang terungkap di sini, yakni: relasi geneologis, analogis, kooperatif, dan historis. Berbagai tipologi relasi inilah juga yang akhirnya menjadi dasar munculnya bentuk-bentuk sinkritisisme budaya di antara keduanya, Dayak-Banjar.
\end{abstract}

Kata Kunci: Etnis Dayak, etnis Banjar, tipologi relasi dan relasi geneologis

\section{Pengantar}

Secara galib, Dayak dan Banjar adalah dua etnis ${ }^{1}$ utama yang mendiami wilayah, yang sekarang secara administratif kenegaraan, propinsi Kalimantan

*Artikel ini merupakan salah satu refleksi dari penelitian yang penulis laksanakan bersama Moh. Soehadha, dan Ahmad Muttaqin pada tahun 2003-2004 dengan tema "Agama Lokal dan Pemberadaban Masyarakat: Eksistensi Kaharingan di tengah Kebijakan Pemerintah dan Misi/Dakwah "Agama Resmi". Subyek penelitian dimaksud adalah mayarakat Dayak Meratus di Kecamatan Loksado, Kabupaten HSS, Kalimantan Selatan. Mitos-mitos yang menjadi data primer artikel ini diambil dari bank data penelitian berupa hasil wawancara dengan dua orang balian di lokasi tersebut, yakni Penghulu Tuha dan Abah Wakal. Nama kedua informan kunci tersebut telah dianonimkan. Untuk itu, penulis menyampaikan terima kasih kepada rekan-rekan peneliti, serta para informan yang bersedia informasi primernya penulis sajikan ulang dalam artikel ini.

** Dosen Fakultas Ushuluddin UIN Sunan Kalijaga dan Koordinator Riset dan Kajian Ilmiah Laboratorium Religi dan Budaya Lokal Fakultas Ushuluddin UIN Sunan Kalijaga Yogyakarta. 
Selatan. Populasi utama masyarakat Banjar berada di sepanjang daerah pesisir sungai dan dataran rendah atau rawa-rawa. Sementara itu, masyarakat Dayak di Kalimantan Selatan mendiami daerah sepanjang Pegunungan Meratus. Karena itulah mereka terkadang juga dinamakan Dayak Meratus dengan merujuk kepada lokasi tersebut. Orang Dayak sendiri diyakini telah mendiami wilayah Kalimantan Selatan lebih awal daripada orang Banjar.

Tanpa menafikan adanya perdebatan tentang asal-usul kedua etnis ini, artikel ini akan berusaha untuk menunjukkan relasi dari kedua etnis ini berdasarkan tuturan dari orang-orang Dayak Meratus. Tuturan-tuturan tersebut terekam dalam bentuk mitos-mitos mereka. Mitos-mitos yang tersaji akan diinterpretasi dengan melihat relasi-relasi yang dibangun di dalamnya untuk menentukan relasi antar imajinasi dan atau memori orang Dayak Meratus tentang hubungan mereka dengan orang Banjar. Mitos-mitos meraka saya pahami sabagai ungkapan simbolik mereka terhadap berbagai pengalaman maupun imajinasi kehidupan yang ada pada pemilik mitos. Untuk sampai kepada urian relasi-relasi tersebut, saya akan memaparkan terlebih dahulu asumsi yang saya gunakan tentang mitos dan pemaknannya.

\section{Simbol dan Makna: Relasi Dalam Mitos}

Manusia dipahami sebagai animal symbolicum yakni makhluk yang mampu menggunakan simbol dalam komunikasi antar mereka. Ungkapan ini

1 Saya menggunakan sebutan etnis untuk kedua kelompok masyarakat ini dengan merujuk kepada pengertian etnis yang dikemukakan oleh Anthony Smith "Structure and Persistence of Ethnic" dalam Guibernau, M. dan John Rex (ed.), The Ethnicity: Reader. (1997) Malden: Blackwell Pub. Inc., h. 27 yang menyatakan bahwa "Ethnic group may be defined as named buman populations with shared ancestry myths, histories and cultures, having an association with a specific territory and a sense of solidarity". Richard D. Lewis menambahkan bahwa "culture can be seen as a set of symbol that determines the people that he/ she belongs to certain ethnic group based on language". Richard D. Lewis (2003) The Cultural Imperative. Yarmouth: Intercultural Press, h. 9. Pengertian pertama menggunakan kategori kesamaan mitos masa lalu, sejarah dan kultur, serta wilayah tertentu dan rasa solidaritas sebagai penanda etnisitas seseorang. Pengertian kedua membatasi lagi peran kultur sebagai penanda etnisitas yang dengan mendasarkan kepada bahasa. Etnisitas seseorang dalam pengertian ini bisa mengalami perkembangan. Perkembangan yang dimaksud bisa terjadi dalam dua hal: pertama, keluar masuknya seseorang ke dalam kelompok etnis yang berbeda-beda karena perubahan elemen-elemen penanda tadi yang bisa didorong oleh berbagai hal, seperti politik, ekonomi, budaya dan lain-lain; kedua, munculnya etnis baru karena dorongan salah satu elemen di atas atau lebih secara bersamaan. Dus, pengertian ini menafikan syarat keaslian dari sebuah kelompok etnis, karena ia bisa terbentuk dan berasal dari etnis lain atas dorongan hal-hal yang variatif. 
senada dengan asumsi filosofis manusia dalam tradisi Arab dengan menyebutnya sebagai al-bayawan al-natiq. Simbol yang dimaksud adalah bahasa, baik lisan maupun tertulis, atau bukan keduanya. Simbol dalam interaksi antar manusia berfungsi untuk menyampaikan makna dari subyek penyampai simbol kepada subyek penerima. Sekalipun demikian, simbol tidak serta merta menunjukkan makna yang diinginkan oleh subyek penyampainya. Alfred Whitehead menamakan proses penggunaan simbol oleh manusia sebagai symbolism yang didefinisikan:

"human mind is functioning symbolically when some components of its experience elicit consciousness, beliefs, emotions, and usages, respecting other components of its experience. The former sets of components are the 'symbols', and the latter set constitute the 'meaning' of the symbols. The organic functioning whereby there is transition from the symbol to the meaning will be called 'symbolic reference ${ }^{\prime \prime \prime 2}$

Ada tiga point utama dalam definisi di atas: (1) dalam simbolisme terdapat dua aspek yang saling berhubungan yakni simbol dan makna; (2) adanya proses transisi dari simbol ke makna yang disebut referensi, dan; (3) simbol berfungsi untuk menggugah munculnya makna yang bisa berupa kesadaran, keyakinan, emosi ataupun gambaran tertentu tentang pengalaman. Point ketiga menunjukkan bahwa simbol hanya berfungsi sebagai pengantar untuk menggugah makna. Tetapi, makna itu sendiri dapat keluar dari pengertian denotatif simbol yang digunakan. Perbedaan makna itu tergantung kepada pengalaman sebelumnya, imajinasi, dan kepentingan terhadap bentuk simbol yang disampaikan dan diterima. ${ }^{3}$

Hubungan simbol dan makna dijelaskan lebih jauh oleh Ferdinand de Sausare dalam relasi sintagmatik dan paradigmatik atau asosiatif. ${ }^{4}$ Relasi sintagmatik menunjuk kepada makna simbol dalam satu rangkaian dengan simbol kata-kata yang lain, sementara relasi paradigmatik ditentukan oleh hubungan suatu simbol kata tertentu dalam suatu rangkaian dengan rangkaian

2 Alfred North Whitehead (1927) Symbolism: its meaning and effect. New York. Capricorn Book h.7-8

${ }^{3}$ Ibid. h.10-12 lihat pula W. Dillistone, (2002) Daya Kekuatan Simbol: The Power of Symbol. Terj. A. Widyamartaya. Yogyakarta. Kanisius

${ }^{4}$ Ferdinand de Saussure. (1966) Course in General Linguistics. New York. McGraw Hill, h. 114. Dalam buku ini Saussure lebih banyak berbicara tentang relai sintagmatik; Lihat juga Heddy Shri Ahimsa Putra (2001) Strukturalisme Levi-Straus: Mitos dan Karya Sastra. Yogyakarta. Galang Press h. 50. 
simbol-simbol yang lain. Rangkaian simbol-simbol yang lain itu bisa berupa konteks atau kepentingan tertentu. Karena itu, relasi sintagmatik-paradigmatik juga dihubungkan dengan makna referensial-kontekstual simbol dan tanda.

Bagi Levi Srauss, Mitos merupakan salah suatu gejala bahasa yang juga memuat asumsi-asumsi filosofis ini. ${ }^{5}$ Sekalipun demikian, mitos bekerja dalam tataran bahasa tertentu, atau tataran bahasa tingkat tinggi. Ketinggian tataran bahasa mitos tersebut dikarenakan relasi simbol dan makna di dalamnya dapat melampaui struktur bahasa biasa. Ia bisa diungkapkan dengan simbol bahasa yang berbeda-beda atau diterjemahkan ke dalam bahasa lain tanpa kehilangan ciri-ciri mitisnya. ${ }^{6}$ Ciri-ciri mitis tersebut ada pada struktur dalam (deep structure) setiap mitos. Untuk mengungkap struktur dalam tersebut mitos harus ditempatkan seperti bahasa yang mempunyai sejumlah fonem. Dalam mitos, fonem-fonem tersebut berupa mytheme atau ceriteme. Ceriteme ini berfungsi sebagai simbol, yang berarti memuat makna referensial, dan tanda, berupa nilai (value) yang terbentuk oleh konteks, sekaligus. Miteme-miteme ini menunjukkan relasi-relasi tertentu di dalam bagian-bagiannya berupa kombinasi berbagai tokoh dan peran mereka masing-masing. Miteme-miteme tersebut kemudian disusun secara sintagmatis dan paradigmatis sehingga melahirkan relasi-relasi yang lebih luas yang menunjukkan makna yang dimiliki oleh si pemilik mitos. ${ }^{7}$ Prosedur inilah yang dinamai sebagai strukturalisme oleh Levi Strauss. ${ }^{8}$

Dalam artikel ini saya tidak akan melakukan analisis strukturalisme di atas, namun, hanya akan memanfaatkan asumsi-asumsi terhadap simbol dan tanda yang dibangun dalam mitos-mitos dalam strukturalisme. Asumsi-asumsi tersebut berupa relasi-relasi antar tokoh, simbol, dan peran masing-masing

5 Sebagaimana dikutip oleh Heddy Shri Ahimsa Putra :"Myth is language, functioning on an especially high level where meaning succeeds practically at "taking off" from linguistic ground on which it keeps on rolling" Ibid. h.85.

6 Ibid.

7 Ibid. h.96.

8 Untuk membedakan dengan strukturalisme yang dikemukakan oleh tokoh-tokoh lain, Ahimsa-Putra mengemukakan empat asumsi dasar dalam strukturalisme Levi Strauss: (1) berbagai aktivitas sosial merupakan bahasa atau perangkat tanda dan simbol yang menyampaikan pesan tertentu. Karenanya ia memiliki aturan dan keterulangan; (2) Setiap manusia memiliki kemampuan dasar untuk menstruktur atau menyusun suatu struktur dari pengalamannya; (3) makna suatu istilah ditentukan secara sinkronik, bukan diakronik, sehingga memungkinkan terjadinya transformasi. Transformasi di sini berarti keterulangan makna dalam struktur yang berbeda; (4) relasi pada struktur dalam dapat diperas menjadi oposisi berpasangan (binary opposition). Lihat Ibid. h. 66-72. 
dalam mitos. Relasi-relasi akan dilihat secara khusus pada relasi Dayak dan Banjar. Sebagai referensi pada simbol dan konteks pada tanda berikutnya saya akan menjelaskan secara sederhana komposisi populasi dan hipotesa asal-usul Dayak Meratus dalam hubungannya dengan Banjar.

\section{Eksistensi Dayak Meratus di Kalimantan Selatan}

Topografi dan populasi Dayak Meratus. Uraian ini langsung ditujukan kepada Dayak Meratus di Kecamatan Loksado, dimana mitos-mitos ini ditemukan. Kecamatan Loksado yang berjarak kurang lebih $70 \mathrm{Km}$ ke arah Barat Laut dari ibukota propinsi Kalimantan Selatan di Banjarmasin merupakan salah satu wilayah tradisional masyarakat Dayak Meratus. ${ }^{9}$ Jaraknya Dari ibukota Kabupaten Hulu Sungai Selatan di Kecamatan Kandangan kurang lebih $40 \mathrm{Km}$ ke Arah Barat atau sekitar 1 jam perjalanan dengan menggunakan angkutan pedesaan roda empat. Luas secara keseluruhan wilayah ini menurut Data Statistik kecamatan Loksado tahun 2002 adalah 338, $89 \mathrm{Km}^{2}$, dengan populasi penduduk 7498 jiwa yang tersebar pada 11 wilayah Desa.

Sebagian besar dari populasi penduduk Kecamatan Loksado adalah orang Banjar dan orang Dayak. Etnis Dayak hampir menghuni pada setiap desa di Kecamatan Loksado, kecuali di Desa Lumpangi dan Halunuk. Etnis Dayak merupakan populasi terbesar di Loksado, yaitu berjumlah 49,59\% dari total keseluruhan penduduk Loksado. Sementara etnis Banjar juga merupakan populasi yang cukup besar jumlahnya di bawah jumlah populasi Dayak, yaitu sebesar 49,54\% (Sumber: BPS HSS 2001). Dari persebaran agama, mereka yang menganut Kaharingan, agama yang diyakini sebagai agama asli orang Dayak, tergolong cukup besar, yaitu sebesar 2.702 (36,04\%). Sementara itu, terdapat sejumlah $3.887(51,85 \%)$ penduduk yang memeluk agama Islam, yang merupakan agama yang diidentikkan dengan orang etnisitas Banjar. 54 orang beragama Katolik, 747 (9,96\%) beragama Kristen Protestan, 86 (1,14\%)

9 Sejumlah wilayah tradisional masyarakat Dayak Meratus lainnya adalah Kecamatan Awayan di Kabupaten Hulu Sungai Utara, Kec. Batang Alai Selatan dan Batu Benawa di Kabupaten Hulu Sungai Tengah, Kecamtan Padang Batung di Kab. Hulu Sungai Selatan, Kec. Tapin Utara di Kab. Tapin, Kecamatan Balimbing di Kab. Banjar, Kec. Sampanahan dan Kalumpang di Kab. Kota Baru. Lihat Noerid Haloei Radam. (2001) Religi Orang Bukit. Yogyakarta. Semesta. h. 71. Data-data terebut disusun Radam sekitar tahun 1979-1980. Saat ini wilayah-wilayah tersebut mengalmai perkembangan baik karena pemekaran wilayah dengan munculnya wilayah adminstratif baru, seperti Kec. Loksado yang dulunya hanya kampung, ataupun pergerakan atau migrasi para penduduknya. Namun penyebab kedua tidak bergerak jauh dari wilayah sekitar pegunungan Meratus. 
beragama Hindu, dan 22 orang (0,29\%) beragama Budha (Sumber: Profil Kecamatan Loksado 2002). Perbandingan populasi etnis Dayak dan Banjar dengan persebaran agama di Kecamatan Loksado, terutama Kaharingan dan Islam, menunjukkan interaksi yang intens antara kedua etnis ini. Intensitas tesebut mendorong terjadi konversi orang Dayak ke dalam Islam, tanpa menafikan agama-agama yang lain. Proses interaksi dan konversi ini juga turut mendorong akulturasi dari kedua pendukung kelompok etnis ini, yang akan tergambar kemudian dalam relasi-relasi yang dibangun dalam mitos-mitos mereka.

Asal-usul Dayak Meratus. Ada perbedaan hipotesa tentang asal-usul Dayak Meratus. Tjilik Riwut mengelompokkan kelompok-kelompok Dayak yang mendiami daerah Kayu Tangi (Martapura sekarang), Pelaihari, Kotabaru dan sepanjang DAS Amandit dan Riam Kiwa ke dalam sub-suku Dayak Ngaju. ${ }^{10}$ Pengelompokkan ini didasarkan atas kemiripan mitos kosmogini mereka, sistem kekeraban yang luas bilateral, serta perladangan berpindah (swidden agriculture). Sekalipun demikian, populasi terbesar Dayak Ngaju terdapat di wilayah propinsi Kalimantan Tengah. Riwut juga menambahkan, bahwa asalusul orang Dayak adalah proto Melayu dari daerah Yunan pada sekitar tahun 200 SM. Gelombang pertama migrasi proto Melayu ini terdesak oleh kedatangan Melayu Muda yang kemudian mendominasi daerah pesisir di dataran rendah, sementara orang-orang proto Melayu menetap di dataran yang lebih tinggi. ${ }^{11}$ Melayu Muda inilah yang kemudian dikenal sebagai orang Banjar.

Radam melihat orang Dayak Meratus lebih dekat kepada orang Banjar Hulu. Kedekatan ini didasarkan atas kedekatan religi dan bahasa mereka, serta sejumlah simbol-simbol yang menunjukkan sinkretisme yang terjadi di antara keduanya. ${ }^{12}$ dia menerima hipotesa desakan pendatang yang membuat orang Dayak yang mesti bermigrasi ke daerah atas. Di daerah baru ini mereka membangun kebudayaan baru dalam sistem bercocok tanam dengan perladangan berpindah. Hal ini dapat dibuktikan dengan masih adanya sejumlah simbol-simbol ritual yang menunjukkan kebudayaan orang pesisir pantai di dataran rendah, seperti Naga, Jukung dll., yang juga kental dalam mitologi orang-orang Banjar. ${ }^{13}$ Jarani, seorang budayawan Banjar yang telah

${ }^{10}$ Tjilik Riwut (1973) Kalimatan Membangun: Alam dan Kebudayaan, Yogyakarta: Tiara Wacana, h.235

${ }^{11}$ Ibid. h. 231

${ }^{12}$ Noerid Haloei Radam, Op. Cit. h.105.

${ }^{13}$ Ibid. h. 102. 
bergaul selama lebih dari 20 tahun dengan orang Dayak Meratus, khususnya di pegunungan Meratus, memahami bahwa bahasa yang digunakan oleh orang Dayak Meratus, terutama dalam mamangan pada saat upacara adalah bahasa Banjar Arkais. ${ }^{14}$ Dalam perkembangan terakhir, bahkan, tidak banyak lagi orang Banjar orang Dayak Meratus di Loksado yang bisa menuturkan bahasa asli mereka, kecuali para balian. Keseharian mereka lebih banyak menggunakan bahasa Banjar dengan dialek yang khas mereka. ${ }^{15}$ Jika menggunakan pengertian etnis dalam catatan kaki no.3 yang mendasarkan pengelempokkan etnisitas seseorang atas dasar bahasa, maka pandangan Radam di atas lebih bisa diterima.

Hipotesa Radam bisa didukung oleh penjelasan J.J. Ras tentang konsentrasi populasi Dayak Ngaju atau Biadju dan Banjar di masa awal. Konsentrasi kedua etnis tersebut memanjang dari Selatan ke Utara dari muara Sungai Barito dan Kahayan. Orang-orang Banjar mendiami wilayah pesisir sungai dan dataran rendah sepanjang sisi Barat pegunungan Meratus yang menjadi titik-titik perkotaan di propinsi Kalimantan Selatan saat ini. Masyarakat Dayak Ngaju berada di Barat dari perkampungan-perkampungan Banjar tersebut. Mereka mendiami wilayah DAS Barito, Kahayan, dan Kapuas Murung, yang sebagian besar berada pada wilayah propinsi Kalimatan Tengah saat ini. ${ }^{16}$ Dengan konsentrasi penduduk tersebut, pergerakan yang lebih dekat untuk masuk dan mendiami wilayah pegunungan Meratus, yang menjadi wilayah tradisional orang-orang Dayak Meratus saat ini, adalah dari perkampungan orang-orang Banjar. J.J. Ras sendiri tidak menjelaskan keberadaan orang-orang Dayak Meratus dalam Hikajat Bandjar. Penjelasan Ras dan Radam di atas dapat dihubungkan bahwa pergerakan yang lebih memungkinkan yang melahirkan orang-orang Dayak Meratus berasal dari moyang orang-orang Banjar Hulu yang bergerak naik ke dataran tinggi sebelum etnis Banjar itu sendiri terbentuk.

Dayak dan Banjar sendiri kemudian diidentifikasi secara berbeda tidak hanya melalui etnisitas, tetapi juga agama mereka. Dayak identik dengan Kaharingan sebagai agama asli mereka. Banjar identik dengan Islam sebagai

${ }^{14}$ Wawancara dengan Uda Jarani tol. 22 April 2003

15 Ahmad Rafiq (2004) "Shifting Identities of the Loksado Dayak in Their Contact with "New-Comers": A Challenge for Empowerment" dalam Fatimah Husen dkk (ed.) Social Work: Indonesian Perspectives and Contemporary Issues. Yogyakarta. Interdisciplinary Islamic Studies Program, UIN Sunan Kalijaga. h. 161.

16 J.J. Ras (1968) Hikajat Bandjar: A Study in Malay Historiography. Netherland. Koninklijk Instituut . h. 195. 
agama yang baru mulai dianut sejak masa Pengeran Suriansyah atau Pangeran Samudera. Kerajaan Banjar, sebelum itu, adalah kerajaan Hindu, yang memiliki hubungan historis yang sangat dekat kerajaan Majapahit di Jawa. PengIslaman massal kerajaan Banjar, beserta seluruh rakyatnya, juga terjadi atas hasil interaksi dengan kerjaaan Demak di Jawa. ${ }^{17}$ Identifikasi agama ini juga kemudian sering digunakan untuk menjelaskan proses konversi agama yang terjadi. Jika seseorang telah masuk Islam, dia akan disebut orang Banjar. Sebaliknya, dia akan tetap disebut Dayak selama masih menganut Kaharingan. Identifikasi ini juga direspon oleh orang Dayak melalui mitos atau cerita mereka pada bagian selanjutnya artikel ini.

Orang-orang Dayak Meratus sendiri mengungkapkan relasi mereka dengan orang-orang Banjar melalui sejumlah mitos atau folklore. Mitos-mitos mereka menjelaskan relasi-relasi tersebut baik secara langsung maupun tidak. Mitos-mitos tersebut saya pahami sebagai seperangkat simbol yang digunakan untuk menyampaikan pesan kepada orang lain, terutama dalam konteks transformasi kepercayaan mereka. Pada bagian berikut ini, saya akan menunjukkan sejumlah relasi simbolik yang dibangun orang Dayak Meratus dalam simbol-simbol mereka.

\section{Relasi-relasi Dayak-Banjar dalam Mitos Masyarakat Dayak Meratus}

Tipologi relasi yang dibangun di sini mengikuti alur tipologis yang disusun oleh Heddy Shri Ahimsa-Putra (2001) ketika menjelaskan relasi antara Islam dan Jawa dalam mitos-mitos Jawa. Istilah-istilah tehnis dalam tipologi tersebut diambil secara denotatif dari makna katanya. Tipologi yang dimaksud adalah relasi genelogis yang menunjuk kepada hubungan genetik dari dua unsur yang dijelaskan relasinya, dalam hal ini Banjar dan Dayak; Relasi analogis yang menunjukkan kepada analog atau permisalan yang digunakan di kedua unsur etnis tersebut; Relasi kooperatif yang berarti hubungan kerjasama di antara kedua etnis ini; Relasi historis yang menunjukkan klaim historis terhadap keberadaan sejumlah artefak yang masih ada atau diakui pernah ada. Sejalan dengan relasi-relasi tersebut, saya juga akan memperlihatkan sinkretisme yang hipotetik pada pilihan-pilihan kata-kata yang diungkapkan dalam mitos-mitos tersebut sebagai hasil dari proses sinkretisasi. 


\section{Relasi Geneologis}

Relasi geneologis dapat dirunut dari dua cerita yaitu mitos 41 Nabi keturunan Datu Adam dan Datu Tihawa serta mitos Si Ayuh dan Bambang Basiwara. ${ }^{18}$ Dalam mitos pertama dituturkan:

- "Datu Adam dan Datu Tihawa mempunyai anak 41 orang, yang kemudian menjadi 40 orang Nabi-nabi. Tetapi satu yang pertama tidak sempat diberi nama, inilah yang terkurung menjadi orang Dayak. Ia menetap di gunung untuk memelihara. Itulah yang bernama anak Adam yang "ditapaakan" di gunung Surapati. Ialah yang diutus untuk memelihara harta milik galib, harta perlindungan. Memelihara di gunung babaris, di gunung babagi. Ialah yang memelihara sarang burung, serta segala harta yang dihasilkan dari gunung, itulah harta karun, harta dunia.

- Anak sulung Adam yang tidak sempat diberi nama ini kemudian menurunkan "Balian Bumbu Raja Walu", hasil perkawinannya dengan anak balian keturunan Datu Intingan. Bumbu Raja Walu ini berjumlah delapan orang yang diperintahkan oleh Datu Adam untuk mengasuh Balian di "perangkatan hari balian, perangkatan bulan". Lalu dibuatlah aturan-aturan "Aruh" dan adat.

- ...Para balian ini wafat di langit, dan tiada berkubur. Semuanya adalah cucu dari Datu Adam, yang semuanya menjadi balian.

- Bumbu Raja Walu inilah yang kemudian menurunkan balian-balian lainnya hingga saat ini."

Mitos kedua menceritakan:

- "Datu Ayuh dan Datu Bambang Siwara adalah dua bersaudara. Bambang Siwara adalah Datu yang bertolak ke kota, dan menurunkan orang Islam, sedang Datu Ayuh bertahan di Gunung dan menurunkan orang-orang Dayak.

- Bambang Siwara memegang kitab, dan mengajak Datu Ayuh untuk berIslam, namun Datu Ayuh menolaknya, ia lebih memilih untuk tetap berada di gunung.

- Bambang Siwara kemudian menurunkan kepintaran, dan Datu Ayuh sebaliknya menurunkan kebodohan. Namun bersamaan dengan itu,

18 terdapat beberapa versi simbol bahasa cerita ini, ada yang menyebutnya dengan Sandayuhan dan Bambang Basiwara, ada yang menambahkan nama Palui di antara keduanya. Palui sendiri adalah tokoh Pak Pandir dalam cerita rakyat Banjar. 
Datu Ayuh juga menurunkan kesaktian kepada orang-orang Dayak. Itulah jadinya Orang-orang Dayak itu bodoh, tapi sakti-sakti.

- Dahulu kala, ketika keduanya sedang berjalan, datanglah banjir besar. Kitab yang dibawa oleh Datu Bambang Siwara dibagi dua menjadi kitab barencong, dan diberikan separonya kepada Datu Ayuh. "Kita bawa kitab ini bersama-sama", ujar Datu Bambang Siwara. Namun Datu Ayuh berpikiran lain, daripada capek-capek membawa kitab ini lebih baik dimasukkan saja ke dalam perut, maka dimakanlah kitab tersebut oleh Datu Ayuh, dibiarkan tersimpan di dalam perut saja. Itulah yang menjadi asal-muasal ajaran orang Dayak yang tersimpan di dalam hati, yakni kitab yang dimasukkan ke dalam perut oleh Datu Ayuh tadi.

- Sementara Bambang Siwara, dengan kitabnya yang masih utuh, menurunkan tradisi tulis-menulis. Segala ajaran mesti dituliskan. Sedangkan Datu Ayuh menurunkan ajarannya dengan keyakinan dan hafalan. Itulah yang menjadi penyebab orang Dayak apabila mengaji sebuah ajaran, sekali melakukan selamatan, langsung hafal. Berbeda dengan orang Islam yang mesti berulang kali, dan dituliskan, karena mewarisi bawaan Datu Bambang Siwara.

- Kedua kakak-beradik ini telah memasang janji, ke mana saja Datu Ayuh dan turunannya pergi, maka akan diikuti oleh Bambang Siwara dan turunannya. Itulah mengapa ke mana saja orang Dayak pergi, pastilah diikuti oleh orang Banjar. Karena pada dasarnya mereka semua adalah bersaudara."

Dalam mitos pertama disebut secara gamblang asal keturunan orang Dayak dari anak pertama dari 41 orang anak Adam. Dalam tradisi Banjar yang Islam, Adam juga dikenal sebagai manusia pertama yang diciptakan Tuhan yang sekaligus menjadi Nabi pertama. Adam dan Hawa kemudian menurunkan 40 orang anak yang saling berpasang-pasangan dan menurunkan umat manusia di berbagai penjuru dunia. Modifikasi penambahan anak Adam dan Hawa menjadi 41 dalam mitos tersebut menyampaikan tiga pesan sekaligus: (1) masyarakat Dayak dan Banjar yang Islam pada dasarnya berasal keturunan genetis yang sama, yakni Adam dan Hawa; (2) anak Adam yang menurunkan orang-orang Dayak adalah anak pertama, sulung, yang menunjukkan klaim historis bahwa mereka lebih dulu ada di wilayah tersebut daripada orang Banjar, sekalipun mereka berasal orang tua yang sama, dan; (3) anak Adam yang menurunkan orang Dayak tidak sempat diberi nama dan menetap di gunung berisi pesan eksistensi mereka yang sempat dilupakan baik dari sisi 
wacana yang disimbolkan dengan nama, maupun dalam interaksi sosial yang disimbolkan dengan tinggal di gunung.

Dalam mitos kedua kembali diulangi relasi geneologis orang Dayak dengan Banjar. Pada bagian ini, orang Dayak kembali menyebut diri mereka sebagai saudara tua-yang disimbolkan dengan Datu Ayuh—dari orang Banjar-yang disimbolkan dengan Datu Bambang Siwara--. Relasi geneologis ini dihubungkan dengan relasi kepercayaan dan sistem transformasi pengetahuan yang berlangsung di kedua etnis tersebut. Relasi kepercayaan berupa kitab yang dibagi menjadi dua. Simbol ini menunjukkan bahwa bagi orang Dayak pada dasarnya kepercayaan mereka berasal dari sumber awal yang sama dan berfungsi saling melengkapi satu sama lain. Sistem transformsi pegnetahuan muncul sebagai konsekwensi simbol relasi kepercayaan. Sistem transformasi lisan dan tulisan merupakan dua ssitem yang saling melengkapi, sekalipun menjadi tekanan dari dua etnisitas yang berbeda. Relasi geneologis ini berfungsi sebagai medium atau pemersatu dari dua ekstrim kepercayaan dan tranformasi pengetahuan tersebut yang saling berlawanan. Relasi itu dapat digambarkan dalam skema berikut:

Datu Ayuh $>========<$ Batu Bambang Siwara

Menurunkan Dayak $>========<$ Menurunkan Orang Banjar

Memakan bagian kitabnya $>========<$ Memegang bagian kitabnya

Transformasi secara lisan $>========<$ Transformasi dengan tulisan

Bodoh tapi sakti $>========<$ Pintar tapi tidak sakti

Menetap di gunung $>=======<$ Turun ke dataran rendah

Semua oposisi tersebut dimediasi oleh kenyataan simbolik bahwa mereka berdua adalah kakak dan adik yang merupakan saudara kandung (relasi geneologis) dan sumber ajaran yang sama sekalipun dengan perlakuan yang berbeda (kitab barencong sebagai relasi keyakinan)

Atas dasar relasi inilah, sejumlah orang Dayak di pegunungan Meratus lebih senang menyebut diri mereka sebagai Dayak Banjar untuk membedakan dengan kelompok dayak lainnya. Dus, orang Banjar sebenarnya adalah Dayak, atau sebaliknya. Positioning seperti ini dapat dipahami sebagai bagian dari negosiasi identitas orang Dayak terhadap stigmatisasi yang dikenakan terhadap mereka melalui politik identitas. Stigmatisasi itu telah berlangsung baik secara struktural maupun kultural yang melahirkan penindasan di kedua aspek tersebut. ${ }^{19}$ Dengan demikian, simbolisasi ini merupakan bentuk resistensi

19 Lihat Bob Mullaly (2002) Challenging Opression: a Critical Social Work Approach, Oxford. Oxford University press. h. 71, 97. 
mereka terhadap bentuk-bentuk penindasan tersebut. seakan-akan mereka berkata: "anda telah menindas bagian dari diri anda sendiri!". Sebuah pernyataan singkat dari seorang Balian di Balai Padang, Malinau menegaskan: "napa nang balain di kami ini, kita ini sama asalnya dari Datu Adam, sama ia warga negara, pemilu umpat jua mancucuk, kanapa maka minta sakulaban haja saling ngalihan?"

\section{Relasi Analogis}

Relasi analogis dapat terjadi dalam bentuk kedekatan simbolik yang digunakan baik pada simbol maupun pada maknanya. Relasi tersebut dapat dilihat pada dua mitos: mitos pertama adalah mitos kosmogini dan mitos kedua berupa legenda raksasa dari langit.

o "Tuhan bersuara: "Bumi dan langit dunia akan kucipta hari ini". Lalu terciptalah bumi dan langit. Langit naik ke atas bumi turun ke bawah. Rata, sama sama rata. Terang benderang bercahaya, seperti surga. Umat manusia, tumbuh-tumbuhan dan hewan pun belum ada.

- Setelah langit dan bumi dicipta, Tuhan bersuara, yang ada hanya suara Tuhan. Karena kehendak Tuhan semuanya akan dicipta seorang wakil, kekasih Tuhan. Dicipta seadanya, maksudnya tidak dicipta dari apapun jua, dari air maupun tanah. Dialah yang dalam bahasa kami disebut dengan Sang Hyang Nining Babatara.

- Kemudian ada lagi suara dari atas: "Hai Sang Hyang Nining Bahatara ciptaanku, Ciptakanlah manusia untuk mengisi bumi yang luas bagaikan surga ini". Sang Hyang Nining Bahatara menyahut: "Bagaimana aku bisa mencipta? Rasanya aku tidak sanggup." Lalu Tuhan menyahut: "Karena engkau sudah Kuperintah, maka pasti bisa." Lalu Tuhan menurunkan setitik air: "Sambut wahai Nining Bahatara ini air setitik! Kunur-kunur ada, kunur-kunur zat". Nur Allah namanya.

- Setelah air tersebut disambut, Tuhan menyuruh Nining Bahatara untuk mengambil tanah dari dasar Ars. Lalu sambut angin, angin putih kuturunkan. Lalu dikepal, lalu tanah dikepal, dibentuk manusia. Dan dicampur. Ternyata salah, hancur. Hal ini diulangi sampai dua kali.

- Dikepal untuk yang ketiga kali, barulah berbentuk manusia. Tetapi meminta makanan darah merah. Lalu Ning Bahatara bertanya kepada Tuhan mengenai apa yang mesti dilakukan. Tuhan memerintahkan makhluk tersebut ke sebelah langit. Jadilah ia raja setan, jadi raja jin, 
yang juga memiliki kuasa di sebelah langit. Kemudian Raja Jin tersebut disandarkan di kayu Sindura.

- Nining Bahatara meminta kembali kepada Tuhan manusia yang sempurna. Untuk mengisi bumi. Lalu Tuhan berkata: "sambut air setitik, ambil tanah sekepal dari dasar ars, campur angin sehelai, dan kepalkan. Ambilkan juga akar balaran surga!" Akar balaran tersebut yang kemudian menjadi urat di tubuh kita. Lalu dikepal lagi. Lalu Tuhan bersuara: "Jadilah manusia yang berwujud dan bernyawa!" Itulah yang kemudian menjadi manusia Datu Adam, manusia yang sempurna.

- Adam berjalan-jalan di muka bumi dan langit yang seperti surga, bersih dan sempurna. Adam berujar kepada Nining Bahatara (Kalau dalam Islam sama dengan Jibril, bukan laki-laki dan bukan perempuan, tetapi kekasih Tuhan yang berada di bawah Tuhan yang maha kuasa, yang berfungsi sebagai perantara, kekuasaannya tiada terhingga, mampu berbicara dengan Tuhan); "apa artinya kalau aku hidup sendirian di sini?" Pada saat itu, tumbuh-tumbuhanpun belum ada ataupun binatang lainnya.

- Adam meminta kepada Nining Bahatara untuk memberikan teman kepadanya. Nining Bahatara menyampaikan permohonan Adam kepada Tuhan bahwa ia menginginkan seorang teman. Lalu Tuhan menyuruh Nining Bahatara untuk mencabut rusuk kiri Adam dan berkata: "Hempaskan ke dasar tiang aras. Baca mantra yang ini”: "Air bunikun Adam nurbuni ja tibawa" maka akan jadilah seorang perempuan, yaitu Datu Tihawa, belahan jiwa Adam. Ambil tulang rusuk tadi, dan lemparkan ke bumi yang luas, maka jadilah Datu Tihawa. Maka dari Adamlah Datu Tihawa berasal. Semua itu berdasarkan kehendak Tuhan.

- Melihat Datu Tihawa, muncul nafsu Datu Adam karena rasa cinta kasih dan sayangnya. Lalu Adam langsung berusaha memeluknya tapi Datu Tihawa menolaknya. Jangankan dipeluk, didekatipun Datu Tihawa menjauh. Datu Tihawa lari dan Datu Adam terus mengejarnya.

- Karena bekas larinya Datu Adam, jadilah bumi ini ada berupa gunung, berupa lubang, yang kemudian menjadi sungai. Habis bulan berganti bulan Adam mengejar Datu Tihawa, sehingga badan menjadi kurus. Begitu bernafsunya Datu Adam, sehingga sirnya (sperma) keluar. Sperma yang berceceran inilah kemudian yang menjadi seluruh binatang yang menyengat, seperti lebah, ular-ularan, kalajengking, semut, macan, dan seluruh isi dunia. 
- Ketika sedang kejar-kejaran, Tuhan mencipta kayu berdiri/kayu surga/kayu besar/kayu seribu ada/kayu seribu lengkap. Buahnya seribu macam. Dengan melihatnya saja orang sudah bisa kenyang. Pada saat berkejar-kejaran, Datu Adam dan Datu Tihawa melewati kayu besar ini. Keduanya terdiam melihat kayu yang mewah ini dan berhenti berkejarkejaran. Dengan melihat saja keduanya menjadi kenyang dan hilang lelahnya.

- Raja Jin dari sebelah langit tadi menyerupa menjadi ular. Ular berkata: "Hai Adam mengapa kau biarkan buah itu?" Adam teringat perkataan Nining Bahatara yang melarangnya untuk memakan buah di pohon itu, karena cukup dengan melihatnya saja sudah kenyang. Ular berkata: "Kamu dibohongi Tuhan dan Jibril. Ini buah kayu yang sangat nikmat, harus kamu makan." Adam percaya kepada perkataan ular, lalu dipetiknya sebiji.

- Dibelahnya dua. Belahan bagian bawah dipegang Datu Adam. Bagian tangkai diserahkan kepada Datu Tihawa. Datu Tihawa masih ragu, maka buah itu hanya dipegangnya. Sementara Datu Adam langsung memakannya. Lalu muncul suara: "Hai... aku ciptakan engkau untuk mengisi dunia, dan kami ciptakan makanan ini cukup untuk dilihat. Sekarang telah engkau langgar." Lalu keduanya menjadi telanjang. Datu Adam menutupkan buah yang tinggal kerongkongnya tadi ke dadanya, jadilah susu kita laki-laki itu kecil. Sementara, buah yang sudah masuk ke dalam mulut tadi, tertahan di leher, jadilah jakun. Sementara yang berada di tangan Datu Tihawa belum dimakan, maka jadilah susu perempuan itu besar. Itulah kisah awal kejadian manusia.

- Sebelum kejadian itu (kejar-kejaran tadi), dunia kita ini rata. Sejak itu hiduplah Datu Tihawa dengan Datu Adam. Setelah dibacakan kata Adam sejodoh, jadilah mereka seperti suami isteri. Keduanya diperintah untuk memenuhi seluruh isi dunia. Sirr keduanya telah sama terbuka. Lalu menciptalah mereka seorang anak manusia."

Untuk memahami relasi analogis dalam mitos di atas terlebih dahulu kita susun tokoh-tokoh yang terlibat di dalamnya serta perannya masingmasing:

\begin{tabular}{|l|l|}
\hline Tuhan (Ilah) & $\begin{array}{l}\text { Mencipta Alam semesta dan mencipta } \\
\text { Sang Hyang Nining Bahtara (Jibril) }\end{array}$ \\
\hline Sang Hyang Nining & Kekasih Tuhan, pelaksana perintah \\
\hline
\end{tabular}




\begin{tabular}{|l|l|}
\hline Bahatara (Jibril) & $\begin{array}{l}\text { Tuhan untuk mencipta Datu Adam, } \\
\text { Datu Tihawa, perantara perintah } \\
\text { Tuhan kepada Datu Adam, melempar } \\
\text { Iblis. }\end{array}$ \\
\hline \multirow{5}{*}{ Raja Jin (Iblis) } & $\begin{array}{l}\text { Ciptaan Manusia yang salah karena } \\
\text { selalu meminta makan darah, penguasa } \\
\text { langit subalah, menjelma menjadi ular, } \\
\text { menggoda Adam dan Hawa untuk } \\
\text { memakan buah yang sudah dilarang. }\end{array}$ \\
\hline Datu Adam & $\begin{array}{l}\text { Manusia Pertama untuk menghuni } \\
\text { Bumi, Pembentuk struktur permukaan } \\
\text { bumi, asal dari tumbuh-tumbuhan dan } \\
\text { binatang yang hidup di bumi. }\end{array}$ \\
\hline \multirow{3}{*}{ Datu Tihawa } & $\begin{array}{l}\text { Partner Datu Adam dalam } \\
\text { menjalankan perannya sejak awal } \\
\text { penciptan sampai menurunkan umat } \\
\text { manusia. }\end{array}$ \\
\hline
\end{tabular}

Mitos kosmogini masyarakat Dayak Meratus di atas memuat perbedaan simbol dibandingkan dengan ajaran kosmogini yang ada dalam Kitab Panaturan. ${ }^{20}$ Kitab ini ditulis oleh sebuah tim dari Majelis Ulama Kaharingan di Kalimantan Tengah. Kitab ini menjadi pegangan bagi pemeluk Kaharingan. Sekalipun demikian keduanya memuat sejumlah kesamaan dalam struktur berpikir. Peran dan kedudukan tokoh-tokoh di dalam mitos ini juga mengalami sedikit perkembangan dari hasil temuan terdahulu. Sebutan untuk Tuhan di kalangan Dayak Meratus bervariasi antara Tuhan, Ilah, Allah, atau Allah Ta'ala. Sebutan-sebutan ini serupa dengan simbol yang digunakan dalam Islam yang dianut oleh orang Banjar. Penamaan manusia pertama dengan Datu Adam dan Datu Tihawa juga menunjukkan relasi simbolik yang sangat dekat dengan penamaan yang sama di kalangan Muslim Banjar. Penambahan Datu pada kedua nama tersebut merupakan tradisi tutur lokal untuk menunjukkan orang yang dihormati atau ditinggikan kedudukan atau kemuliaannya. Istilah yang sama juga digunakan dalam tradisi tutur orang Banjar, misalnya sebutan Datu Kalampayan untuk menyebut Syekh Muhammad Arsyad Al-Banjari, ulama

${ }^{20}$ Bajik R. Simpei dan Mantikei R. Hanyi. (1996) Panaturan: Tamparan Taluh Handiai (Awal Segala Kejadian). Palangkaraya. Majelis Besar Alim Ulama Kaharingan Indonesia. 
terbesar dalam sejarah Islam di Kalimantan Selatan, dan lain-lain. ${ }^{21}$ Kehadiran Raja Jin yang juga disebut Iblis atau setan juga menunjukkan relasi simbol yang sama di kalangan Muslim Banjar. pemberian alternasi Raja Jin atau Iblis menunjukkan penempatan simbolik Iblis sebagai bagian dari Jin yang terkuat atau sebaliknya. Simbol ini juga sangat besar kemungkinan sentuhan dengan informasi yang sama tentang kedudukan kedua jenis makhluk tersebut di kalangan orang Banjar. Secara bahasa istilah-istilah tersebut merupakan istilah Islam di kalangan orang Banjar yang diderivasi dari bahasa Arab, bahasa Kitab Suci Umat Islam.

Perkembangan kedudukan dan peran tokoh dalam mitos terjadi pada kasus Nining Bahatara. Hasil catatan terdahulu, dari sejumlah peneliti, Nining Bahatara—terkadang juga disebut Sang Hyang Nining Bahatara-merupakan sebutan lain untuk Tuhan. Simbol yang sama sekarang digunakan untuk menunjukkan peran yang dimainkan oleh perantara antara Tuhan sang pencipta dengan manusia ciptaanya, Adam yang menurunkan para Nabi. Nining Bahatara pun kemudian diidentikkan dengan Jibril. Sebutan Jibril atau Jabaril sendiri sudah dikenal sebelumnya dalam mitos-mitos orang Dayak sebagai Malaikat, tetapi tidak dalam peran sebagai perantara. Pergeseran peran ini membentuk kesejajaran relasi analog simbolik dalam mitos Dayak dengan keyakinan Islam yang dianut orang Banjar, sekalipun peran penciptaan dalam kosmogini Islam tidak pernah menggunakan perantara. Kesejajaran tersebut dapat digambarkan sebagai berikut:

\begin{tabular}{|l|l|l|l|}
\hline \multicolumn{2}{|c|}{ Dayak } & \multicolumn{2}{c|}{ Banjar-Islam } \\
\hline Tuhan, Ilah. & $\begin{array}{l}\text { Tuhan tertinggi di } \\
\text { langit }\end{array}$ & Allah & $\begin{array}{l}\text { Tuhan sang Pencipta di } \\
\text { langit }\end{array}$ \\
\hline $\begin{array}{l}\text { Sang Hyang } \\
\text { Nining } \\
\text { Bahatara }\end{array}$ & $\begin{array}{l}\text { Perantara } \\
\text { Perintah Tuhan }\end{array}$ & Jibril & $\begin{array}{l}\text { Perantara Perintah } \\
\text { Tuhan kepada Nabi }\end{array}$ \\
\hline Datu Adam & $\begin{array}{l}\text { Manusia Pertama } \\
\text { yang menurunkan } \\
\text { Para Nabi di } \\
\text { bumi }\end{array}$ & Adam & $\begin{array}{l}\text { Manusia Pertama, Nabi } \\
\text { Pertama yang } \\
\text { menurunkan para Nabi } \\
\text { di bumi }\end{array}$ \\
\hline
\end{tabular}

${ }^{21}$ Fahrurraji Asmuni. (2002) Cerita Datu-Datu Terkenal Kalimantan Selatan. Kandangan Kal-Sel. Sahabat 
Tuhan dan Adam di kedua keyakinan ini ditempatkan sebagai oposisi berlawanan di langit dan di bumi, sementara kehadiran Sang Hyang Nining Bahatara dan Jibril menjadi mediator dari dua ekstrim tersebut. ${ }^{22}$

Relasi analog lainnya dapat dilihat dalam mitos berikut:

"Suatu ketika turunlah raksasa besar dari langit membuat kekacauan di muka bumi, dia memakan setiap orang yang ditemuinya dan mengahancurkan pohon dan tanam-tanaman yang ada di gunung. Mendengar kabar tersebut, berangkatlah Datu Ayuh untuk menghadapi sang raksasa. Datu Ayuh beusaha menghadapi dengan kesaktian yang dimilikinya, namun tidak berhasil mengalahkan raksasa tersebut. Disampaikanlah pesan kepada Datu Bambang Siwara. Datu Bambang Siwara kemudian pergi untuk mengumpulkan 99 macam racun yang mau dipakai untuk menembak raksasa. Datu Bambang Siwara naik ke gunung dengan membawa sumpit yang telah dilumuri 99 macam ramuan. Ketika bertemu dengan Raksasa itu, ditujukanlah kepadanya sumpitnya. Namun ternyata sumpit tersebut belum sanggup meruntuhkan sang raksasa. Datu Bambang Siwara pun pergi untuk mencari kekurangan dari ramuan panah yang telah dibuatnya sampai akhirnya ditemukan. Pada saat hendak menyumpit diucapkanlah satu kalimat melengkapi menjadi seratus ramuan, sehingga sang raksasapun kalah, dan lari kembali ke langit."

Sejalan dengan mitos terdahulu bahwa Datu Bambang Siwara adalah cikal bakal orang Banjar yang beragama Islam, maka simbol bilangan 99 dapat dipahami sebagai analog dari 99 nama Tuhan, sedangkan satu kalimat terakhir sebagai penyempurnanya adalah kalimat tauhid "La Ilaha illallah".

\section{Relasi kooperatif}

Relasi kooperatif berupa informasi simbolik tentang kerjasama yang berlangsung di antara orang Dayak dan orang Banjar. Relasi ini dapat terlihat dari mitos raksasa perusak dari langit di atas. Dalam mitos tersebut kehadiran kembali Datu Bambang Siwara ke gunung untuk membantu menyelesaikan masalah yang dihadapi Datu Ayuh merepresentasikan kerjasama kedua kelompok masyarakat dalam menghadapi masalah. Simbol raksasa dari langit dapat ditafsirkan sebagai gangguan di tengah komunitas Dayak yang berasal dari luar, bukan dari kalangan masyarakatnya atau alam sekitarnya. Jikalau

22 Pergeseran peran ini bisa dibandingkan dengan Radam, Op.Cit. 
gangguan itu berasal dari alam sekitarnya, maka orang Dayak jelas lebih memahami cara menghadapinya. Dalam mitos kosmogini terdahulu dapat ditangkap pesan kedekatan orang Dayak dengan alam sekitarnya. Kedekatan itu tergambar lewat tumbuhan dan binatang yang berasal dari sirr Adam yang berarti bumi beserta isinya sebenarnya merupakan bagian dari diri manusia. Pada fase selanjutnya, anak Adam yang pertama, yang menurunkan orangorang Dayak, bertugas untuk menjaga Gunung beserta segala tanamannya. Keadaanya menjadi lain, ketika gangguan itu berasal dari luar yang sudah melibatkan pengetahuan dan kekuatan yang berada di luar jangkauan mereka. Untuk itu mereka membutuhkan bantuan saudara mereka yang "pintar" untuk menghadapinya. Makna simbolik kekuatan dari luar tersebut bisa berupa kekuatan negara atau mesin-mesin raksasa yang hendak mengeksploitasi alam mereka. ${ }^{23}$

Relasi kooperatif juga tergambar dalam mitos Matundang Kaling berikut:

○ "Dahulu kala ada seorang sakti bernama Matundang Kaling, ia hamil setelah meminum air dari daun tarap. Setelah melahirkan diberilah nama anaknya Sumali'i. Hari demi hari semakin besar, sampai telah bisa duduk. Sementara itu kemarau masih terus berlangsung. Pada saat itu sang anak telah bisa berbicara dan menagih meminta air kepada ibunya karena kahausan. Minum lewat susu ibu juga tidak memadai, karena susu Matundang Kaling telah kering pula. Kembali Matundang Kaling mencari air di setiap hulu sungai, di setiap gunung. Tiada pula ia menemukan air, bahkan akar sekalipun juga kering.

- Sampailah Matundang Kaling di Hulu Barito, di sana ia menemukan sebuah pohon besar, berteduhlah Matundang Kaling di pohon tersebut. Sementara itu ia terus memasang telinga, sehingga mendengar bunyi binatang, eek..eek.., bunyi binatang lamtinik, binatang penunggu mata air. $\mathrm{Hal}$ ini isyarat bahwa ada air di sungai yang kering tersebut. Dengan semangat yang tinggi mulailah Mutandang Kaling mengeruk tanah tersebut, hari demi hari, sampai sebulan lamanya, ketika ia menemukan batu ampar (lempeng) yang sangat besar, sekitar seratus meter persegi besarnya. Tapi tetap tidak menemukan air.

${ }^{23}$ Stepanus Djuweng. (1999) "Pembangunan dan Marginalisasi Masyarakat Adat Dayak: Suara dari Kalimantan" dalam Muhammad Hidayat Rahz (ed.) Manuju Masyarakat Terbuka: Lacak Jejak Pembaruan Sosial di Indonesia. Yogyakarta. Insist Press. 
- Sementara sang anak didudukkan di sisi lain tempat ia mengeruk sungai yang kering tersebut, sambil terus meminta aing (air) kepada sang indung (ibu) karena kehausan: Indung adakah aing? Ujar sang anak, "belum" jawab Matundang Kaling, sambil terus berusaha memcahkan batu besar tadi. Bunyi pertanda adanya air di bawah semakin keras, namun airnya belum juga tampak. Ketika batu besar tersebut berhasil diangkatnya, tiba-tiba keluarlah air yang sangat besar, sehingga menghanyutkan sang anak yang sedang duduk di bilir tempat ia berdiri.

- Sambil berteriak Matundang Kaling menyuruh anaknya untuk tidak banyak melihat kesana-kemari, berpegangan saja di rumput-rumput di sepanjang arus air yang menghanyutkannya. Namun sang anak tak mampu mencapainya, sehingga terus terhanyut dan hilang. Matundang Kaling terdiam menangis, sakit hatinya rasanya.

- Begitu sakitnya rasa hati, Matundang Kaling berusaha untuk bunuh diri. Naiklah ia ke atas pohon besar tadi. Dari dahan tertinggi, ia melompat ke bawah, namun tubuhnya jatuh dengan lembut, seperti sehelai daun, sehingga gagal usahanya untuk bunuh diri. Ia berusaha menemukan penyebab kegagalannya tersebut, sadarlah ia bahwa hal ini mungkin karena salipang/basal (ikat pinggang yang telah diisi berbagai kesaktian) yang digunakannya. Dilepaslah salipang tersebut, disangkutkan di sebilah dahan. Matundang Kaling kembali naik ke puncak pohon besar tersebut, melompat, sehingga matilah ia. Tinggallah mayat tersebut sebagai penjaga hulu sungai Barito.

- Di sisi lain, sang anak, terus terhanyut dibawa arus, hingga ke sisi laut, laut simpang walu. Genap tujuh hari tujuh malam terdampar di sisi laut tersebut, sang anak bertapa di tempat tersebut, tiba-tiba kepalanya menjadi delapan (walu). Tubuhnya menjadi besar. Ia bertekad untuk mudik ke pabuluan, (hulu sungai Barito, tempat ia terpisah pertama kali dari indungnya) untuk mencari indungnya. "Di mana Indungku" ujarnya, padahal indungnya telah meninggal. Sambil berjalan ia terus berujar" iling-iling ada uyang, iling-iling ada uyang", maksudnya lihat-lihat kalau-kalau ada orang yang dicarinya. Sampai ia di Batu Batian, bertemu seseorang, disumpahnya jadi batu, maka jadi batulah orang tersebut. Dilewatinya kebun tebu, disumpah jadi batu, maka jadilah batu, lewat kebun pisang disumpah jadi batu, makalah jadilah batu. Sampai di Batu Menjangan juga disumpah jadi batu, maka jadilah batu. Sampai di balai di Batu Laki, disumpah pula jadi batu, jadilah batu. 
- Sampailah kabar berita tersebut kepada Datu Ayuh dan Datu Bambang Siwara. Keduanya sepakat bila Sumali'i dibiarkan maka semua isi dunia akan menjadi batu, habislah umat manusia. Sepakatlah pula mereka untuk mencari getah ratus (campuran dari berbagai getah pohon yang beracun) untuk dijadikan sumpitan. Keduanya berjaga berseberangan sungai, di jalan menuju hulu Barito, yang akan dilewati Sumali'i.

- Ketika Sumali'i sudah terlihat, dilihatnyalah Datu Ayuh hendak menyumpitnya, disumpahnya jadi batu. Pada saat kelingking Datu Ayuh nyaris jadi batu, Bambang Siwara dari seberang segera meyumpitnya, kena, maka matilah Sumali'i."

Akhir episode mitos di atas kembali memperlihatkan kerjasama antara orang Dayak dan Banjar yang disimbolkan dengan dua saudara terdahulu. Kerjasama ini kembali terjadi dalam konteks menghadapi gangguan yang berasal dari luar yang mengakibatkan kerusakan terhadap alam mereka. Media perlawanan terhadap gangguan tadi juga disimbolkan dengan bilangan ratus yang bermakna seratus. Bilangan seratus di sini sama dengan total bilangan 99 ramuan dan satu kalimat pada mitos dalam relasi analogis di atas. Bilangan inilah yang berhasil mematahkan gangguan dari luar tersebut.

Dari kedua contoh mitos yang memuat relasi kooperatif ini ada hubungan yang tidak seimbang antara orang Dayak dan orang Banjar. Orang Banjar dengan simbol Datu Bambang Siwara selalu ditempatkan sebagai penolong akhir dari sang kakak. Munculnya ekspresi mitos tersebut dari orang Dayak bisa dimaknai sebagai proses hegemoni dari orang Banjar-meminjam istilah Gramsci ${ }^{24}$ - terhadap orang Dayak. Oposisi berpasangan pada relasi geneologis terdahulu ditengahi oleh keberadaan kedua subyek yang beroposisi sebagai saudara kandung sehingga mempunyai relasi yang seimbang. Pada relasi kooperatif ini, orang Dayak justeru menempatkan Orang Banjar sebagai saviour, juru selamat. Berbagai komponen pada diri Datu Bambang Siwara justeru menjadi kelebihan yang tidak dimiliki oleh Datu Ayuh. Kelebihan ini dimunculkan justeru pada persolaan yang dihadapi oleh Datu Ayuh sendiri. Ada dua hal yang mungkin melahirkan hegemoni ini,: pertama, bentuk gangguan yang berada di luar kemampuan generik orang Dayak untuk mengatasinya, sebaliknya orang Banjar memilikinya, dan; kedua, akibat dari stigma dan

${ }^{24}$ Mansur Fakih (2004) "Gramsci di Indonesia" Pengantar pada edisi Indonesia Roger Simon. Gagasan-gagasan Politik Gramsci. Terj. Kamdani dan Imam Baehaqi. Yogyakarta. Insist press. h. xviii. 
stereotip yang berlangsung lama. ${ }^{25}$ Stigma dan stereotip ini menjadikan orang Banjar superior, dan orang Dayak sebaliknya. Superioritas Banjar dan inferioritas Dayak ini kemudian terinternalisasi-meminjam isitlah Berger dan Luckman $^{26}$ - atau merasuk ke dalam kesadaran orang Dayak, dan akhirnya diterima sebagai kenyataan obyektif lewat simbol mitos.

Bentuk relasi kooperatif yang lebih seimbang tergambar jelas dari penutup mitos Datu Ayuh dan Datu Bambang Siwara di atas, yang bertutur: "Kedua kakak-beradik ini telah memasang janji, ke mana saja Datu Ayuh dan turunannya pergi, maka akan diikuti oleh Bambang Siwara dan turunannya. Itulah mengapa ke mana saja orang Dayak pergi, pastilah diikuti oleh orang Banjar. Karena pada dasarnya mereka semua adalah bersaudara." Dalam tuturann ini orang Banjar selalu berinteraksi secara kooperatif dengan orang Dayak lebih karena alasan geneologis, bukan karena superioritas.

\section{Legenda Kerajaan Kayu Tangi : Relasi Hitoris}

Relasi historis dibangun berdasarkan penggunaan simbol artefak atau tempat yang dapat dirunut secara nyata. Relasi tersebut dapat dapat dibaca dari mitos Kayu Tangi berikut:

○ "Orang Dayak dahulu kala menghuni daerah kerajaan Kayu Tangi, yang merupakan cikal bakal kerajaan Banjar. Wakil Raja, Nini Masin Bapati, menyeberangi sungai, pada saat yang bersamaan dilihatnyalah anak raja juga menyeberang dengan mengangkat kain, sehingga tampaklah olehnya paha yang putih bersih, bangkitlah birahi sang wakil raja. Sejak itu Iapun jatuh hati kepada anak raja, siang malam terus terbayang.

- Diberanikannyalah untuk bertanya kepada raja perihal Putri Galuh Banjar, anak raja, sang raja meludah, karena tak mungkin ia mengawinkan anaknya hanya dengan seorang wakil raja yang mukanya pun buruk, sekalipun sakti, yang mampu menyeberangi sungai Kayu Tangi hanya dengan satu langkah.

${ }^{25}$ Lihat Anna Lowenhaupt Tsing. (1998) Di Bawah Bayang-bayang Ratu Intan. Terj. Achmad Fedyani Saifuddin. Jakarta. Yayasan Obor Indoensia; Radam. Op. Cit, Ras. Op/. Cit, Moh. Soehadha, Ahmad Rafiq dan Ahmad Muttaqin (2003) "Agama Lokal dan Pemberadaban Masyarakat: Eksistensi Agama Kaharingan di tengah Kebijakan Pemerintah dan Misi dan Dakwah Agama "Resmi"" Laporan Penelitian pada Lembaga Ilmu Pengetahuan Indonesia, Jakarta.

${ }^{26}$ Peter L. Berger dan Thomas Luckman. (t.t.h) The Social Construction of Reality: A Treatise in the Sociology of Knowledge. New York. Anchor Books. h. 61, 114; Mullaly, Op. Cit. h. 140. 
- Karena merasa malu, larilah Nini Masin Bapati ke gunung. Sampailah ia di muara Amandit, di gunung Tanginau, Bertapalah beliau di sana. Sambil bertapa beliau meminta hujan tujuh hari tujuh malam, turunlah hujan sehingga air sungai Amandit menjadi hitam. Banjir besarpun datanglah, Nini Masin Bapati, bertekad hendak bunuh diri, menceburkan diri ke dalam banjir besar tersebut, karena rasa malu yang bersengatan.

- Ketika hendak melompat muncullah seekor naga betina besar, dengan janggut yang besar, dan mata yang bersinar kuat. Melompatlah Nini Masin ke dalam ombak besar, seketika itu pula sang naga melompat dan menariknya untuk berpegangan di tanduknya, dilemparkannya kembali ke samping, "engkau tidak boleh mati" ujar sang naga. Ketika hendak melompat lagi, muncullah sang Naga jantan, Sangkar Walu namanya, "engkau tidak boleh mati" ujarnya, "aku hendak bunuh diri karena rasa malu telah ditolak mengawini putri raja, aku tidak mungkin lagi kembali ke Kayu Tangi".

- Dibiarkanlah ia berjalan menuju teluk yang dalam, "berhentilah di sini" ujar sang naga, "aku akan memakanmu hingga mati", ditelanlah Nini masin Bapati oleh sang naga, ditelan pertama dikeluarkan, hingga tiga kali. Sang Naga kemudian memerintahkannya untuk kembali ke Kayu Tangi, sementara sang naga pergi menghilang.

- Setelah peristiwa itu wajah Nini Masin Bapati, (raja Senopati) berubah menjadi sangat ganteng. Sebelum raja Senopati kembali ke Kayu Tangi, di kota sang putri Galuh Banjar, terkenang kepada raja Senopati. Ketika ditemui ke kota, sang putri meminta agar ia dilamar kembali, namun raja Senopati menolaknya karena dahulu telah dipermalukan. Raja Senopati kembali ke gunung, sementara putri Galuh jatuh sakit, karena jatuh cinta. Tiga bulan sakitnya tidak sembuh-sembuh, karindangan (sakit karena terkenang orang yang dikasihi).

- Raja tersadarkan bahwa harus ia yang memohon kepada raja Senopati agar sudi menerima anaknya. Karena apabila dibiarkan maka anaknya satu-satunya akan meninggal. Pergilah sang Raja menemui Senopati, dan bersedia memenuhi berapapun yang diminta asalkan bersedia menerima anaknya. Maka jadilah raja Senopati berjodoh dengan putri Galuh Banjar, dilangsungkanlah perkawinan untuk mereka berdua."

Ada dua tempat yang menjadi setting cerita di atas yang yakni Kayu Tangi dan Gunung Tanginau, Muara Sungai Amandit. Melalui tokoh Nini 
Masin Bapati kedua tempat ini disimbolkan sebagai tempat asal orang Dayak. Di tempat asal ini mereka hidup bersama dalam satu komunitas dengan orang Banjar yang diwakili tokoh Raja dan Putri Galuh cikal bakal orang-orang Banjar. Kayu Tangi sebagai cikal bakal kerajaan Banjar juga disebut dalam Hikajat Bandjar. ${ }^{27}$ Gunung Tanginau di Muara Sungai Amandit yang melintasi pegunungan Meratus mengisyaratkan perpindahan orang Dayak dari dataran rendah ke dataran Tinggi. Pada saat yang bersamaan, relasi ini juga menjadi salah satu jawaban terhadap sejumlah simbol ritual masyarakat Dayak Meratus yang menunjuk kepada tradisi air di dataran rendah seperti yang disinyalir oleh Radam. ${ }^{28}$ Di antara simbol-simbol itu adalah naga yang diyakini adanya di air, bukan di gunung; jukung yang merupakan kendaraan sungai berair tenang, bukan jeram seperti di pegunungan. Sekalipun saat ini orang-orang Dayak Meratus hidup di pegunungan, dengan karakter sungai yang berupa jeram, namun secara historis mereka juga berasal dari dataran rendah di mana mayoritas orang Banjar saat ini berdiam.

Ungkapan yang lebih tegas tentang relasi historis ini disampaikan oleh seorang balian:

"Dayak Loksado, dalam sejarahnya, dulu berasal dari daerah Kayu Tangi (wilayah Banjarmasin sekarang), namun dengan kedatangan penjajah Belanda, mereka terdesak mundur sampai ke pegunungan Meratus di daerah Hulu Sungai (Pahuluan). Jadi orang Dayak itu dulu awalnya berasal dari daerah kerajaan Kayu Tangi, pada zaman sebelum Belanda, yaitu zaman Spanyol, Portugis. Dayak itu sebenarnya juga Banjar asli, Dayak Banjar. Jadi orang Banjar dan orang Dayak itu sebenarnya bersaudara. Oleh karena itu, Dayak Loksado sebenarnya juga dapat disebut sebagai Dayak Banjar. Namun, setelah penyelenggaraan Pemilu yang pertama kali itulah, lalu Dayak Loksado disebut dengan Dayak Kaharingan. Saat ini orang-orang Dayak di Loksado (khususnya di daerah Pahuluan) tidak mungkin lagi mundur, sebab di sana (menunjuk ke belakang) ada Kotabaru, di sana (menunjuk ke depan) ada Kandangan, karena tidak mungkin mundur lagi, akhirnya menetap saja lagi di gunung."

Relasi historis ini juga digunakan oleh orang-orang Dayak Loksado sebagai politik identitas. Politik identitas dinyatakan dengan ungkapan

\footnotetext{
${ }^{27}$ J.J. Ras. Op. Cit. h. 48 dst.

${ }^{28}$ Radam, Op. Cit. h. 105
} 
"bersaudara", "Dayak itu Banjar asli", dan "Dayak Banjar". Dalam konsep perlawanan terhadap penindasan yang dikemukakan Mulaly, politik identitas biasa digunakan orang untuk berhadapan dengan stereotip superioritas dan inferioritas pemilik identitas tertentu. Politik ini digunakan oleh pemilik identitas yang dianggap inferior untuk mensejajarkan eksistensi mereka. ${ }^{29}$ Dalam politik tersebut yang mereka gunakan adalah integrasi, yakni menjadikan mereka sebagai bagian dari pemilik identitas superior. Politik ini juga digunakan oleh orang Dayak Meratus terhadap hubungan mereka dengan orang Banjar. Untuk menghindari konflik dalam politik identitas tersebut, mereka memunculkan identitas ketiga yakni Belanda, Spanyol, dan Portugis sebagai penyebab disintegrasi mereka, bukan orang Banjar. Relasi ini dapat digambarkan pada skema berikut dengan menempatkan Kayu Tangi sebagai pusat relasi pada integrasi, dan kekuatan luar (Belanda, Spanyol, dan Portugis) pemecah relasi pada disintegrasi dari dua oposisi berlawanan mereka, Dayak di gunung yang berarti "atas" dan Banjar di "bawah":

$\underline{\text { Integrasi }}$

$$
\text { Banjar (di "Bawah") } \rightarrow \text { berasal dari Kayu Tangi } \leftarrow \text { Dayak (di "Gunung") }
$$

\section{Disintegrasi}

Banjar ("Bawah") >--- Belanda, Portugis Spanyol ---〈 Dayak (di Gunung)

\section{Sinkretisme Dayak dan Banjar (Islam) dalam simbol-simbol Dayak Meratus}

Sinkretisme sebagai hasil dari sinkretisasi dalam konteks ini hanya dimaksudkan sebagai bagian dari perbincangan akulturasi. ${ }^{30}$ Dengan pengertian ini sinkretisme dalam budaya tidak melahirkan pengertian negatif atau positif terhadap hasil proses tersebut. Sinkretisme hanya menunjukkan perkembangan pertemuan dari dua entitas atau kulutr yang berbeda. Sinkretisme ini ditujukan pada beberapa contoh ungkapan yang sudah disampaikan pada sejumlah mitos terdahulu. Sebagian dari sinkretisme ini juga telah disinggung pada beberapa bagian terdahulu.

Dalam mitos-mitos yang mengungkap relasi geneologis simbol Tuhan yang terkadang disebut Ilah jelas sekali terbaca sinkretisme dengan ajaran Islam yang dianut orang Banjar. hal itu bisa dibuktikan oleh dua hal: (1) penyebutan ilah hanya digunakan oleh orang-orang Dayak Meratus, di mana merekalah

\footnotetext{
${ }^{29}$ Mullaly. Op. Cit. h. 101

${ }^{30}$ Ahimsa-Putra. Op. Cit. h. 349
} 
orang Dayak yang berinteraksi dengan orang Banjar; (2) simbol kata ilab sendiri sebenarnya serapan bahasa Banjar dari bahasa Arab yang merupakan bahasa asli Islam. Masih dalam mitos yang sama, penamaan manusia pertama dengan kata dasar Adam dan Hawa juga jelas menunjukkan sinkretisme penamaan tersebut dengan nama yang sama dalam keyakinan Islam orang Banjar. Ungkapan-ungkapan lain yang kental pengaruh Islam yang dianut orang Banjar adalah Tiang 'Arsy yang juga memiliki yang sama dalam Islam sebagai tempat di mana Tuhan bertahta; sejumlah malaikat, seperti Jabaril (terkadang disebut langsung Jibril), Surapil yang serupa dengan Israfil, Mukail yang juga serupa dengan Mikail.

Sinkretsime lainnya yang sangat kental dengan tradisi pengetahuan orang Banjar adalah penyebutan kitab barencong. Dalam mitos Datu Ayuh dan Datu Bambang Siwara, kitab barencong merupakan simbol dari kitab yang dibagi dua dengan memotong secara silang atau barencong. Separo kitab tersebut menjadi ajaran orang Dayak yang non-literer dan harus diajarkan dengan kekuatan jiwa. Dalam tradisi Islam Banjar, istilah yang sama juga dikenal namun digunakan untuk menyebut kitab ajaran tasawuf dari seorang ulama besar Banjar. Kitab tersebut berisi ajaran ketuhanan dan tasawuf tingkat tinggi. Sampai saat ini teka-teki keberadaan kitab tersebut dan makna barencong yang sebenarnya masih belum terjawab secara pasti dalam tradisi Islam Banjar. ${ }^{31}$

\section{Catatan Akhir: Ke mana Relasi Dayak dan Banjar akan Bergerak?}

Relasi-relasi Dayak dan Banjar dalam mitos-mitos Dayak Meratus di atas hanya sebagian kecil dari simbol ungkapan pengalaman pemilik mitos dalam berinterkasi dengan kelompok masyarakat lainnya. Dari relasi-relasi tersebut, paling tidak, ada dua hal yang paling menonjol: pertama, keinginan besar orang Dayak untuk diapreasiasi secara seimbang dengan kelompokkelompok etnis lain di luar mereka. Perjuangan yang sebenarnya orang Dayak Meratus bukanlah memastikan asal-usul mereka seperti pada relasi geneologis atau historis, tetapi perjuangan untuk dilihat sebagai entitas yang sederajat dalam interaksi sosial yang lebih luas. Kesejajaran ini mencakup kesejajaran kultural maupun struktural. Kesejajaran tersebut tidak hanya dipicu oleh sebuah kepentingan budaya dalam sinkretisme, tetapi lebih jauh hak hidup mereka secara layak dan adil sebagai manusia, warga negara, dan anggota masyarakat. Relasi kooperatif di atas di satu sisi dapat bermakna sebagai

${ }^{31}$ H.M. Marwan. (2000) Manakib Datu Nuraya: Misteri Kitab Barincong. Rantau Kal-Sel. T.B. Datu Sanggul. h. 38-41. 
hegemoni Banjar terhadap Dayak, tetapi di sisi lain berisi teriakan tuntutan keberpihakan kepada mereka. Relasi-relasi tersebut akan terus mereka bangun untuk menyuarakan kepentingan-kepentingan mereka yang tersumbat. Dalam kurun waktu terakhir, mitos-mitos dengan relasi-relasi di atas menjadi spirit dari orang Dayak Meratus untuk mengorganisir diri mereka untuk menyuarakan kepentingan mereka. ${ }^{32}$

Kedua, mitos-mitos di atas juga sarat dengan "lampu kuning" tentang kerusakan alam mereka yang diakibatkan oleh kekuatan luar. Raja Jin yang harus dilempar ke alam subalab karena akan menghabisi makhluk hidup yang lain, Sumali'i yang mengutuk semuanya menjadi Batu, serta Raksasa dari langit yang menghancur semua tanaman di gunung. Simbol "alam subalab", Sumali'i, dan langit menunjukkan bahwa kerusakan alam itu akan datang dari luar. Raja Jin, Sumali'i, dan raksasa dari langit bisa berbentuk apa saja yang datang menghancurkan alam dan lingkungan mereka. Mereka bisa berupa kebijakan yang tidak peka terhadap alam, ${ }^{33}$ kekuatan modal yang menafikan kelestarian alam, dan lain-lain. Pada saat yang bersamaan, perlawanan Datu Ayuh dan Datu Bambang Siwara merupakan simbol penolakan mereka terhadap stigma yang dikenakan kepada mereka sebagai peladang berpindah yang merusak alam, justeru merekalah yang menjaganya. Sekalipun demikian, keterlibatan Datu Bambang Siwara dalam dalam perlawanan tersebut mungkin kontradiktif dengan kenyataan saat ini, di mana mungkin banyak "anak cucu" Datu Bambang Siwara dan sebagian "anak cucu" Datu Ayuh yang menjadi "rekanan" Raja Jin, Sumali'i, dan raksasa dari langit.

Secara objektif, sinkretisasi Dayak dan Banjar sendiri akan terus berlangsung dengan komposisi dan dominasi yang mungkin berubah-ubah dalam sinkretismenya. Tetapi perkembangan itu tidak lantas mencacat salah satu atau kedua entitas budaya yang bersinkretisasi. Proses ini justeru akan semakin menumbuhkan semangat multikulturalisme, di mana setiap pendukung budaya yang bersinkretisasi akan merasakan ada bagian dari diri

32 Sebagai contoh berawal dari berdirinya Persatuan Pemuda Dayak di paruh terakhir tahun 90-an, kemudian didirikannya LMMDKS (Lembaga Musyawarah Masyarakat Dayak Kalimantan Selatan), berlangungnya Kongres Masyarakat Adat yang mengumpulkan hampir semua perwakilan masyarakat di Dayak di Kalimantan Selatan, dan lahirnya Permada (Persatuan Masyarakat Adat) yang didasari oleh semangat antitesa terhadap kebijakan pemerintah yang tidak memihak kepada mereka.

${ }^{33}$ Kompas Senin 23 Mei 2005 melaporkan kegagalan proyek "turun Balai" PKAT dari Departemen Sosial. Kegagalan itu lebih disebabkan oleh ketidakpekaan pengambil kebijakan dalam memahami realita sosial dan kultural swidden agriculture masyarakat Dayak. 
mereka yang sama. Perasaan seperti ini justeru positif menjadi media integrasi dalam pengertian peredam konflik antar budaya. ${ }^{34}$ Sinkretisasi itu sendiri merupakan salah satu hukum alam dari interaksi antar budaya, tanpa menafikan adanya relasi kepentingan dalam setiap prosesnya. Tetapi di dalam setiap kelompok pendukung budaya tentu saja akan ada yang mengaffirmasi atau sebaliknya menegasi proses tersebut, Wallabu a'lam []

\section{DAFTAR PUSTAKA}

Asmuni, Fahrurraji, Cerita Datu-Datu Terkenal Kalimantan Selatan. Kandangan Kal-Sel. Sahabat, 2002.

Baihaqi. Imam. "Doa Bersama di Sorowajan: Integrasi Di antara Konflik Institusi Agama" dalam M. Jadul Maula (ed.) Ngesubi Desa Sak Kukuban: Lokalitas Pluralisme Modal Sosial Demokrasi. Yogyakarta: LKiS. 2002.

Berger, Peter L. dan Thomas Luckman. The Social Construction of Reality: A Treatise in the Sociology of Knowledge. New York. Anchor Books. t.t.h.

Dillistone, W., Daya Kekuatan Simbol: The Power of Symbol. Terj. A. Widyamartaya. Yogyakarta. Kanisius, 2002

Djuweng, Stepanus, "Pembangunan dan Marginalisasi Masyarakat Adat Dayak: Suara dari Kalimantan" dalam Mubammad Hidayat Rahz. (ed.) Manuju Masyarakat Terbuka: Lacak Jejak Pembaruan Sosial di Indonesia. Yogyakarta. Insist Press, 1999.

${ }^{34}$ Pernyataan ini merupakan hipotesa penulis dengan merujuk secara sederhana kepada sejumlah kasus di mana masyarakat yagn relatif terbuka dalam hubungan antar budaya, sehingga memudahkan terjadinya sinkretisasi, relatif lebih harmonis dalam menjalani pluralitas agama. Lihat misalnya konsep C. Geertz tentang filosofi stabilisasi Jawa dalam Clifford Geertz (1981) Abangan Santri dan Priyayi, terj, Aswab Mahasin Bandung: Pustaka Jaya; lihat juga Imam Baihaqi (2002) "Doa Bersama di Sorowajan: Integrasi Di antara Konflik Institusi Agama" dalam M. Jadul Maula (ed.) Ngesuhi Desa Sak Kukuban: Lokalitas Pluralisme Modal Sosial Demokrasi. Yogyakarta: LKiS 
Fakih, Mansur, "Gramsci di Indonesia" Pengantar pada edisi Indonesia Roger Simon. Gagasan-gagasan Politik Gramsci. Terj. Kamdani dan Imam Baehaqi. Yogyakarta. Insist press. 2004.

Geertz. Clifford. Abangan Santri dan Priyayi, terj, Aswab Mahasin Bandung: Pustaka Jaya; 1981.

Marwan. H.M. Manakib Datu Nuraya: Misteri Kitab Barincong. Rantau Kal-Sel. T.B. Datu Sanggul. 2000.

Mullaly, Bob, Challenging Opression: a Critical Social Work Approach, Oxford. Oxford University press. 2002.

Putra, Heddy Shri Ahimsa, Strukturalisme Levi-Straus: Mitos dan Karya Sastra. Yogyakarta. Galang Press. 2001.

Radam, Noerid Haloei, Religi Orang Bukit. Yogyakarta. Semesta. 2001.

Rafiq, Ahmad, "Shifting Identities of the Loksado Dayak in Their Contact with "NewComers": A Challenge for Empowerment" dalam Fatimah Husen dkk (ed.) Social Work: Indonesian Perspectives and Contemporary Issues. Yogyakarta. Interdisciplinary Islamic Studies Program, UIN Sunan Kalijaga. 2004.

Rafiq, Ahmad. dan Ahmad Muttaqin "Agama Lokal dan Pemberadaban Masyarakat: Eksistensi Agama Kaharingan di tengah Kebijakan Pemerintah dan Misi dan Dakwah Agama "Resmi'"' Laporan Penelitian pada Lembaga Ilmu Pengetahuan Indonesia, Jakarta. 2003.

Ras, J.J. Hikajat Bandjar: A Study in Malay Historiography. Netherland. Koninklijk Instituut. 1968.

Riwut, Tjilik, Kalimatan Membangun: Alam dan Kebudayaan, Yogyakarta: Tiara Wacana. 1973.

Saussure., Ferdinand de, Course in General Linguistics. New York. McGraw Hill. 1966. 
Simpei, Bajik R., dan Mantikei R. Hanyi. Panaturan: Tamparan Talub Handiai (Awal Segala Kejadian). Palangkaraya. Majelis Besar Alim Ulama Kaharingan Indonesia. 1996.

Smith, Anthony, "Structure and Persistence of Ethnic" dalam Guibernau, M. dan John Rex (ed.), The Ethnicity: Reader. Malden: Blackwell Pub. Inc. 1997.

Tsing, Anna Lowenhaupt. Di Bawah Bayang-bayang Ratu Intan. Terj. Achmad Fedyani Saifuddin. Jakarta. Yayasan Obor Indoensia; Radam. 1998.

Whitehead, Alfred North, Symbolism: its meaning and effect. New York. Capricorn Book. 1927. 
